\section{I heard it as much as I felt it: my experience of a complete proximal hamstring rupture}

\author{
Michelle Dyer
}

I heard it as much as I felt it when the accident happened. I was waterskiing for the first time in 20 years and lost my balance as I was coming up out of the water. My legs straightened just as the boat hit speed and then I heard the snap. Thirty minutes later paramedics hauled me up the steep steps from the dock, strapped to a backboard, high over their heads. I was immediately worried about how this was going to impact my commitment to being active in my 40 s and my new cycling hobby (figure 1).

\section{INITIAL DIAGNOSIS: SOMETIMES IT'S ZEBRAS}

Theodore Woodward coined the phrase, "when you hear hoof beats, think of horses not zebras". My consulting emergency room physician rightly assumed it was a hamstring strain-in his mind it was a horse. Back home in London 4 weeks later I met my sport and exercise medicine specialist, Dr Phil Batty at Isokinetic, who confirmed with his in-office ultrasound scanner that the muscle was retracted. This was a zebra-and not one for conservative management! He sent me for an MRI, which confirmed a full avulsion of the proximal hamstring tendon. It was $15 \mathrm{~cm}$ retracted, and I definitely needed surgery.

Professor Fares Haddad performed the surgery 5 weeks after my injury. I had read some articles and learnt that surgeries for proximal hamstring tears within the first 3 weeks of injury are technically easier, and delays can be associated with less favourable results and larger incisions. I was aware that the muscle can atrophy, and be more difficult to put back in place, and the sciatic nerve can get trapped in scar tissue at the site of the tear. ${ }^{1}$ I was worried that I had waited too long and that I might not be able to walk properly again, but knowing that my surgeon was the author of many of these articles made me feel confident in his abilities. I was well-informed and prepared to work hard to the best possible outcome.

Massachusetts, USA

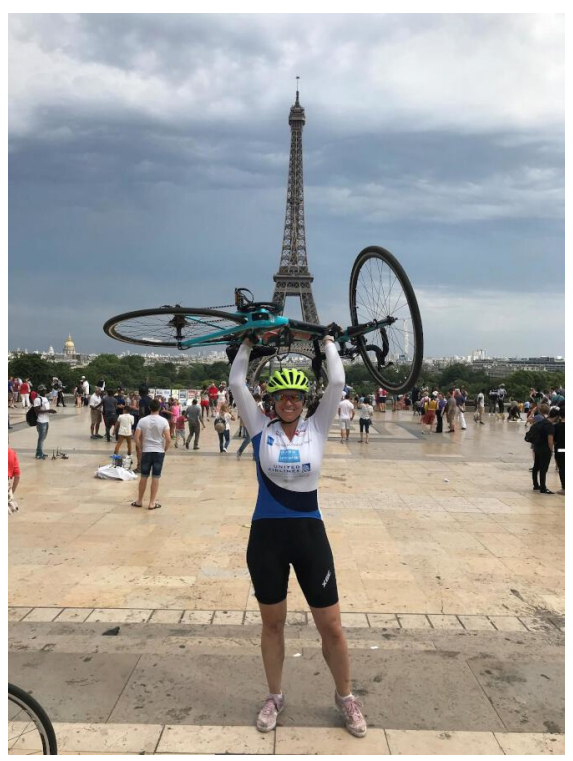

Figure 1 Michelle Dyer celebrating the completion of a charity cycle ride from London to Paris. Copyright: Michelle Dyer.

Full avulsion injuries are not common; in fact, my insurance company representative said that they didn't have a diagnostic code for it as it simply didn't happen enough to justify one. When presented with my symptoms, the consulting physician rightly assumed the most common diagnosis of a hamstring strain. A simple ultrasound might have revealed this retraction and I could have been referred to surgery more quickly. I was fortunate to have an excellent surgeon who was able to make the repair and I am likely to make a full recovery.

\section{PAIN MANAGEMENT: OXYCODONE IS NO JOKE}

I tried to be stoic on the day of the accident and refuse medication, but after the third time I fainted trying to get out of bed the team administered $10 \mathrm{mg}$ of oxycodone. I was discharged with a 7-day supply of oxycodone, but without either counselling on tapering strategies nor guidance towards the possibility that I may suffer withdrawal symptoms even after a short time of using this opioid medication.
A week later I was stunned by the fear of stopping my medication. My rational mind fed the fear of becoming another casualty of the opioid epidemic. I knew, logically, I was just afraid of pain and feeling the side effects of opiate withdrawal. I knew it was temporary and so was my pain. I knew I was strong. I'm an executive in a global corporation and a mother, with friends and family to lean on, and good health insurance, and yet I was overwhelmed with anxiety. I couldn't help but think about those without a support system, and worse, those with chronic pain. If I was struggling like this, how difficult must it be for others who are not so fortunate?

\section{RECOVERY: SOCIAL SUPPORT IS CRITICAL}

Transitioning off pain medication was just one stage of recovery for which the support of my family, friends, colleagues, care team and others was a critical success factor. While I was in the hospital for surgery, my nanny brought my 7 -year-old daughter to her first day of school. While I was in surgery, my team stepped up and managed a deal close with professionalism. A friend picked me up from the hospital and brought me safely home. My family brought me meals, ran our home so I could rest, and gave me space to work through the frustration of being immobile and focus on my recovery.

When my wound got infected, Professor Haddad's senior nurse patiently cleaned, packed and re-dressed it every couple of days for 3 weeks until it healed. Through months of recovery, Dr Batty and my physiotherapist, Ludovica Gagliardi, have led a team of clinicians who have brought me from not being able to move my leg to being able to walk and cycle, and soon run! This team celebrated my first steps, exercised with me, danced with me and held my hand as I cried from frustration during the occasional setback. The group-based rehabilitation model allowed me to offer my support to other patients and be inspired by those recovering from similar injuries, especially the professional athletes in my group who motivated me to come back stronger.

\section{CLOSING THOUGHTS}

My road to recovery has been a lifechanging challenge. I am grateful for the network of people who have supported me along the way and I am certain I will be stronger-physically and mentally-from this experience. I invite clinicians to keep 


\section{Patient voices}

these three things in mind when treating patients with similar injuries:

1. Emergency attending physicians, if there is a simple test that can confirm or definitively rule out a rarer and time-sensitive injury in the emergency room, please consider it.

2. Be very cautious about prescribing opioids, and don't underestimate the challenges your patient might face when transitioning off them, and offer patients support and guidance on how to manage that transition.

3. I cannot overstate the benefits of the cohesive model of a team approach to treatment (physician, surgeon, physiotherapist, nurse) and groupbased recovery and rehabilitation. I was blessed with an amazing team of physiotherapists and fellow patients. Is this a model that can be implemented more widely?

Here's to a full recovery for me, and everyone suffering from sports injuries!

Funding The authors have not declared a specific grant for this research from any funding agency in the public, commercial or not-for-profit sectors.

Competing interests None declared.

Patient consent for publication Not required.

Provenance and peer review Not commissioned; internally peer reviewed. (c) Author(s) (or their employer(s)) 2020. No commercial re-use. See rights and permissions. Published by BMJ.

A) Check for updates

To cite Dyer M. Br J Sports Med 2020;54:1373-1374.

Accepted 6 July 2020

Published Online First 26 August 2020

Br J Sports Med 2020;54:1373-1374.

doi:10.1136/bjsports-2020-103004

\section{REFERENCE}

1 Konan S, Haddad F. Successful return to high level sports following early surgical repair of complete tears of the proximal hamstring tendons. Int Orthop 2010;34:119-23. 